оскільки попри позитивну динаміку та помітні результати реформування за напрямом об'єднання територіальних громад існує низка негативних факторів.

Ключові слова: бюджетна децентралізація, місиеві бюджети, міжбюджетні відносини, бюджетне регулювання.

УДК 338.23-049.5

L. Kyslova

V. Suk

\title{
TRANSFORMATIONAL RECONSTRUCTIONS OF THE SYSTEM OF THE ECONOMIC SECURITY OF UKRAINE
}

The scientific article states that the implementation of measures to ensure economic security, as a key element in the structure of national security, is a fundamental factor in the existence of Ukrainian statehood, which in turn requires the creation and operation of the relevant system. The current state of the system of economic security of the state does not allow to effectively counteract the existing and potential threats, and to create conditions for the stable functioning of the domestic economy. A necessary step for this is the involvement of representatives of international non-governmental organizations and domestic scientific institutions specializing in the study of problems in the economic sphere. Proposed to conduct a systematic audit of the effectiveness of the economic security entities, in order to determine the need for their further reorganization.

Key words: economic system, economic security, threats of economic security, economic indicators.

DOI 10.34079/2226-2822-2020-10-20-39-48

Problem statement. Today, Ukraine is a direct participant in the events that change not only Europe but the whole world. Unfortunately, our country has found itself at the epicenter of the geopolitical transformations, which have resulted in its violation of its territorial integrity and inviolability by the Russian Federation, and have provoked a number of economic challenges. Under such conditions, the issue of studying the institutional and legal aspects of the transformation of the national system of economic security and all its elements becomes especially important.

The analysis of the recent researches and publications. Such scientists, as: Tymoshenko O., Vlasyuk O., Sak T., Sukhorukov A., Malishko V., Chubukova O. and others, devoted their research to the study of the processes of formation of the system of economic security of the state and the development of its areas. At the same time, most scholars do not pay enough attention to the need for the institutional and legal transformational constructions in the system of the economic security of our state.

The purpose of the article. The purpose of the article is to outline the shortcomings of the domestic system of counteracting threats to the economic security of Ukraine and to determine the institutional and legal framework for its transformation in accordance with the modern realities.

The presenting of main material. An important role in the national security system of any country is given to economic security as the basis of the well-being of the nation. The national legislation declares that the state policy in the spheres of national security and defense is aimed at the ensuring military, foreign policy, state, economic, informational, environmental, and cyber security of Ukraine (Закон України Про національну безпеку України..., 2018). 
However, to date there is no legislative definition of the term "economic security", which opens the way for its interpretation by the scientists.

According to the minds of the native scientists as I.F. Binko and V.T. Shlemko, "economic security is a state of the national economy that allows to maintain the resistance to internal and external threats and is able to meet the needs of the individual, family, society, state" (Шлемко та Бінько, 1997). At the same time, V. Mutrian claims that the economic security is a national set of the measures aimed at the constant and stable development of the state economy and includes a mechanism for counteracting the internal and external threats (Мунтіян, 1999). Such a set of the measures should be implemented by the system of the economic security formed in the state. The analysis of the scientific works showed the lack of a holistic approach to the definition of the term "economic security system". Thus, most scientists proceed from the general scientific interpretations of the concept of "system". D.M. Zhylin considered the system as a set of the elements arranged in a certain sequence, in the corresponding definite order, which has the integration properties (Жилин, 2004). In turn, V.N. Sadovsky, defines the system as organized in a certain way by many elements which are interconnected and form some holistic unity (Садовский, 1974). The researcher O.Y. Chubukova defines the system of the economic security as a complex integrity and, at the same time, the separation of the various interconnected subsystems and elements that interacts with the environment as the unity and is separated from it. (Чубукова та Воронкова, 2014). In turn, S.I. Urba refers to such elements objects (economic resources and factors of production), subjects (authorities, society), threats (negative factors), indicators (indicators) (Урба, 2017). In our opinion, the system of the economic security is a set of the integrated, constantly interacting and interconnected elements and subsystems that ensure the balanced existence of the interests of the individual, society and state through the monitoring, detection (identification), neutralization or minimization of the negative influence of the internal and external threats to the economic sovereignty.

The creating and the ensuring of the functioning of the system of the counteracting threats to the economic security of the country is one of the key factors in the ensuring of the state security. The analysis of the effectiveness of its operation allows to identify the existing shortcomings, to determine the ways to eliminate them, increase the effectiveness of the detection, prevention, termination, real and potential threats (risks) for the economic security of the state.

To assess the effectiveness of the system of the response to the threats to the national economic interests, the native scientist M.M. Shevchenko (Шевченко, 2015) proposed a system of the criteria for the following indicators: effectiveness (the ratio of planned resource costs to actual consumption); efficiency (the ratio of the resources that were expected to be spent with the actually consumed ones); quality (a measure of the compliance of the actual results with the requirements and expectations put forward to them); adequacy (the ratio of the resources and costs in the relation to the state response to the threats to the national interests).

Interesting in theoretical terms is the approach proposed by P.M. Dmytruk (Дмитрук, 2013) to identify and respond to threats to economic security at the regional level by compiling a threat passport, which can be extended to the national level. The researcher proposes: at the first stage - identification and determination of parameters of threats to economic security, at the second stage - monitoring, forecasting, quantification of the consequences of threats to economic security, at the third - design, detailed development of the scheme to reduce threats to economic security, at the fourth stage state regulation of economic security through a system of expert assessments (for example, on a 10-point scale, the maximum score is 10, the minimum one is 1). The assessment has to correspond to such criteria as the reliability and validity of the information on the level of the economic security; the completeness and accuracy of the prompt identification of the factors that have a negative impact on the economic security; the quality 
of the economic-engineering grounds of the adopted management's decisions. According to the author, this, using the arithmetical mean, allows you to assess the effectiveness of the system as a whole, as well as its particular indicator. However, in our opinion, the threat passport proposed by the scientist is a static document that does not correspond to the requirements of modern realities, which are characterized by the high dynamics of changes in all spheres of the country's life. And the implementation of such an assessment by the scientists also doesn't take into account the functions of the authorities as for the monitoring of the threats to the economic security, in particular, their quantitative and qualitative assessment of the threats to the economic security, the development forecast, as well as the clarifying of their hierarchy.

The up-to-date state of the system of counteracting to the threats of the economic security is quite precisely defined in the analytical report of the National Institute for Strategic Studies: "Ukraine's national security system has proved to be incapable of the effective resisting to Russian aggression. The security and defense sector as the main component of the national security system is still not fully formed and is not ready to act as a single functional structure“. (Аналітична доповідь..., 2018). The main reason for this is that the approaches to the planning and development of the economic security system are largely outdated and are implemented inconsistently. The successful reformation and improvement of this system are possible only on the basis of clear legal regulation of its composition, structure and functions. Also, the system must be effectively integrated into the system of the international and regional security as an integral part of them.

At the same time, we cannot fully agree with the opinion of some scholars (Резнікова, О.О., ред., 2015) as for the need to intensify the transfer of the experience of the EU countries in the creating and functioning of the European security system in practice by the strengthening of the cooperation with the Eurozone countries and adapting the national legislation, as their political, economic and geopolitical situations are radically different from the similar ones in Ukraine. The immediate hybrid threats and risks from the Russian Federation, the systemic institutional problems of the post-Soviet past, in our deep conviction, are the determining factors that cause the fundamental differences in the reforming of the system of the ensuring of the economic security. However, the practice of the responding to the global threats that have a multidimensional nature and the economic consequences (for example, caused by COVID19) can be applied in the national security space.

It is important to note that in Ukraine the state system of the counteracting to the threats in the field of the economic security is in a permanent state of the formation. In particular, the indicators of the state of the economic security have a recommendatory nature and are not included into any document of the economic security legislation, the creation of a unified system of monitoring, analysis, forecasting and decision-making in the field of the economic security is ignored. At the same time, a single strategic level document has not been developed up to now, which will define the legal basis for the establishment and operation of the system of the response to the threats in the economic sphere, the list, the powers, the order of the interaction of the actors of its ensuring, the indicators, their thresholds in the quantitative and qualitative terms. The National Security Strategy adopted in 2015 (Резнікова, О.О., ред., 2015) turned out to be a purely declarative document that did not take into account the existing realities, the provisions of which, although were reflected in the adoption of the tactical plan documents (Розпорядження Кабінету Міністрів України Про схвалення Енергетичної стратегії..., 2017, Розпорядження Кабінету Міністрів України Про схвалення Стратегіï..., 2019), but they have not found their effective implementation. At the same time, the adopted target program documents lead to incoordination of efforts to achieve the set goals and duplication of functions of individual entities, form a selective approach to the program goal, on the principle of "what they could do", scatter limited material resources. In the conditions of the absence of common understanding and mutually agreed approaches of the 
executive bodies to counter the threats to the economic security, the measures defined in the target programs are actually reduced to simple duplication of direct functional tasks or measures aimed at solving urgent problems of these bodies and relevant areas. Given the above, the main factor that determines the lack of a comprehensive state system for responding to threats to economic security, in our opinion, is the institutional weakness of state strategic management and planning, which leads to measures to respond to existing and potential threats in manual, "fire" mode.

This, in our opinion, is due to frequent changes in the geopolitical vector of Ukraine's development (multi-vector policy 1991-2004, pro-European policy 2005-2010, pro-Russian policy 2010-2013), and hence the lack of a sustainable systemic approach to the formation of directions of state institutions, including in the field of economic security. This clearly demonstrates the chaos in the adoption of guiding regulations, as the main provisions of the "Sustainable Development Strategy Ukraine - 2020" approved on January 12, 2015 (Указ Президента України Про Стратегію сталого розвитку..., 2015) are not based on the National Security Strategy of Ukraine, as the latter was approved later, namely September 14, 2020 (Указ Президента України Про рішення Ради національної безпеки..., 2020). In turn, the fundamental strategic document is the Law of Ukraine "On National Security", adopted on June 21, 2018 (Закон України Про національну безпеку України..., 2018). Thus, not only the logic of preparation and approval of these documents is violated, but also the multiplicity of priority tasks is artificially created. The implementation of structural reforms by the Sustainable Development Strategy is seen as a prerequisite for raising living standards in Ukraine, and among the priorities are deregulation, business development and tax reform (Резнікова, О.O., ред., 2015), while the National Security Strategy, in terms of ensuring the economic component economic relations. (Указ Президента України Про рішення Ради національної безпеки..., 2020).

In practice, the subjects of economic security are deprived of a centralized vector, which should be set by the Law of Ukraine "On National Security", the Strategy of Economic Security and the relevant target programs. A significant number of entities, whose activities are regulated by dozens of regulations, is a negative factor that makes it impossible to organize and implement systematic, adequate, targeted measures to respond to existing and potential threats to economic security.

In this situation, the main principle of the reforming of the sphere of the economic security the principle of systematization should be, which means that the subsystem of the economic security of Ukraine is considered as a single object of forecasting and planning. The activities of its subjects should be aimed at obtaining, in accordance with their competence, the information on the current state and the presence of the threats to the economic security. Another problematic issue is that Ukraine's economic security is still based on the principle of the responding to the deviations from the safe levels, that is the methodology of the passive security is used. Thus, the measures to respond to the threats are taken "post factum" after their occurrence. This approach leads to the loss of the possibility of timely detection and appropriate response at the stage of their origin. This is complicated by the fact that the subjects of the economic security ignore the prognostic component in the process of making the certain decisions. For example, the monetary policy of the National Bank of Ukraine led to the revaluation of the hryvnia by more than $30 \%$ in 3 years. The lack of the forecasting of the economic consequences has led to the fact that in the context of the restrictive measures to combat COVID-19, due to the unjustified strengthening of the national currency, the additional economic costs were incurred by the exporting companies, which, in turn, negatively affected the production and foreign economic indicators of the economic security. 
Taking into account the above, it is advisable to take the following measures:

1. With the involvement of the representatives of the international organizations and the native scientific institutions to analyze the state of the economic security system, in order to determine its critical vulnerabilities, the effectiveness of the responding to the existing and potential threats, the need for their transformation. In particular, this approach is used in the UK, where the Government Office for Science acts as an independent arbiter on the theoretical and technical issues of the risks assessment. The examination of the final results of the assessment is carried out by the group of the scientists - advisors. (Резнікова, О.О., ред., 2020).

2. To provide the organization of the simultaneous external (involving the representatives of the expert community) and internal (by the forces of the subject) audit of the state of involvement subjects (law enforcement agencies, public authorities and local governments, research institutes, etc.) into the ensuring of the economic security. The key points of the assessment should be the ratio of the completeness and adequacy of the implementation of the statutory tools to the modern threats in the economic sphere, the ratio of budgetary resources spent on the maintenance of the subject to his level of the impact on the economic security. Based on the result of the analysis, adjust the quantitative composition of the subjects of the economic security.

3. To adopt a new version of the Law "On National Security" as a basic document for the long term. The Law should define: the concept of the economic security, its components and indicators; the priority areas of economic security; a list of the economic security actors and functions related to its components. In our opinion, it is expedient to include not only the law enforcement bodies, but also the state institutions that implement financial and economic policy: The National Bank of Ukraine, The Ministry of Finance, The Ministry of Economic Development, Trade and Agriculture.

4. Taking into account the fact that the National Security and Defense Council involves in the analysis of the information the officials and the specialists of the executive authorities, government agencies, scientific institutions, enterprises and organizations of all forms of ownership (Закон України Про Раду національної безпеки..., 1998 ), it is considered to be appropriate to expand the powers of the Main Situation Center of Ukraine, which will accumulate and generalize the information on the current state of Ukraine's economic security, the trends of its deterioration or improvement, the external and internal factors that will affect it, including the changes in the geopolitical space, the monitoring of the situation in the foreign commodity and financial markets, the information on the state of the corruption, the organized crime, the activities of the native financial-industrial groups. The data for the needs of the center must be granted by the ministries, by the National Bank of Ukraine, by the State Statistics Service of Ukraine, by the National Commission for State Regulation of Financial Services Markets, by the law enforcement agencies, by the Foreign Intelligence Service (in the terms of the changes in the external environment), by the local governments. An analytical report should be prepared on a quarterly basis (in case of the urgent need - immediately), which will be approved at the meeting of the National Security and Defense Council. The undoubted advantage of this approach is the use of the multifaceted analysis of a wide range of specialists, the efficiency and dynamism in the process of preparing the proposals for the adjustments into the economic security policy, the working out of the possible scenarios of changes in the security environment, the responding to the potential and existing challenges and threats. At the same time, in our opinion, the pluralism of the assessments provides the opportunities to obtain a broader information and analytical base, and to develop on its basis an effective mechanism for the implementing the state policy to combat the threats to the economic security.

5. It is an extremely important step to ensure the communication and the mutual compliance to the Law of Ukraine "On the National Security" as a long-term document, adopted on its basis "National Security Strategy" and "Economic Security Strategy" as the medium- 
term documents, and approved by the Cabinet of Ministers of Ukraine the forecasts of the economic and social development of Ukraine, and the relevant target programs as the shortterm documents, which will aim, if to be implemented, to neutralize the identified threats to the economic security. At the same time, it is necessary to determine the order of control and establish the responsibility for the implementation of the planned measures. However, the adoption of the best standardized documents in any field, without complying with their provisions - is meaningless. Taking into account, that in Ukraine the issue of the assessment of the effectiveness of the implementation of the documents in the field of the economic security is not provided by the current regulations, it is considered to be appropriate to include in the norms of the Economic Security Strategy the procedure for analyzing the effectiveness of the realization of the planned tasks by the economic security entities, and the using of the measures of the reaction, in case of the detection of the unfoundedness of their non-fulfillment.

Such an algorithm can provide a harmonious balance of the national and departmental approaches to the formation of the development strategies of each entity and the sector of the subsystem of economic security as a whole. This, in addition to the organizational aspect, is a real tool to reduce the level of the threats to the economic security in some areas. In particular, the actual implementation of these policy documents will result into the innovative development and the development of the strategically important industries that would take into account the current global trends of the changes in the technological patterns, and will be an important tool for the national interests in the economic sphere, and reduce the threat of the prevalence in the structure of the export of the raw materials, with its further replacement by the high-tech products.

The Conclusions. Thus, on the basis of the conducted research it was found out, that in the modern conditions the ensuring of the economic security of the state largely depends on the availability of the effective system for responding to the existing and potential threats, and it will also allow to coordinate the functioning of its individual elements. It is determined that today in Ukraine there is a need for institutional and legal measures to transform the economic security system. Additionally, the ways and the directions of the priority transformations were proposed.

\section{Бібліографічний список}

Аналітична доповідь до щзорічного Послання Президента України до Верховної Ради України «Про внутрішне та зовнішне становище України у 2018 роиіі», 2018. Київ: Національний інститут стратегічних досліджень.

Дмитрук, П.М., 2013. Інституціоналізація механізму державного регулювання економічної безпеки Автономної Республіки Крим. Кандидат наук. Автореф. Національна академія державного управління при Президентові України.

Жилин, Д.М., 2004. Теория систем: опыт построения курса. 2-е изд. Москва: УРСС.

Закон України Про національну безпеку України, 2018 р. [онлайн] Доступно: $<$ https://zakon.rada.gov.ua/laws/show/2469-19> (Дата звернення: 13.09.2020).

Закон України Про Раду національної безпеки $і$ оборони України, 1998. [онлайн] Доступно: <https://zakon.rada.gov.ua/laws/show/183/98-\%D0\%B2\%D1\%80\#\%3E> (Дата звернення: 20.09.2020).

Мунтіян, В.І., 1999. Економічна безпека Украӥни. Київ: КВІЦ.

Резнікова, О.О., ред., 2015. Концептуальні засади розвитку системи забезпечення національної безпеки України. Аналітична доповідь. Київ: Національний інститут стратегічних досліджень.

Резнікова, О.О., ред., 2020. Наџіональні системи оцінювання ризиків і загроз: кращзі світові практики, нові можливості для України. Аналітична доповідь. Київ: Національний інститут стратегічних досліджень. 
Розпорядження Кабінету Міністрів України Про схвалення Енергетичної стратегії України на період до 2035 року “Безпека, енергоефективність, конкурентоспроможність”, 2017 р. [онлайн] Доступно: $<$ https://zakon.rada.gov.ua/laws/show/605-2017-\%D1\%80\#Text> (Дата звернення: 09.09.2020).

Розпорядження Кабінету Міністрів Украӥни Про схвалення Стратегії сприяння залученню приватних інвестииій у сільське господарство на період до 2023 року, 2019 p. [онлайн] Доступно: <https://zakon.rada.gov.ua/laws/show/595-2019$\% \mathrm{D} 1 \% 80 \#$ Text> (Дата звернення 13.09.2020).

Садовский, В.Н., 1974. Основания общей теории систем: Логико-методологический анализ. Москва: Наука.

Указ Президента Украӥни Про рімення Ради національної безпеки і оборони України від 6 травня 2015 року "Про Стратегію національної безпеки України», 2015. [онлайн] Доступно: < https://zakon.rada.gov.ua/laws/show/287/2015\#Text> (Дата звернення: 09.09.2020).

Указ Президента України Про Стратегію сталого розвитку «Україна - 2020», 2015. [онлайн] Доступно: <https://zakon.rada.gov.ua/laws/show/5/2015\#Text> (Дата звернення: 15.09.2020).

Указ Президента України Про рішення Ради наџіональної безпеки і оборони України від 14 вересня 2020 року "Про Стратегію національної безпеки Украйни", 2020. [онлайн] Доступно: <https://zakon.rada.gov.ua/laws/show/392/2020\#Text> (Дата звернення: 20.09.2020).

Урба, C.I., 2017. Система економічної безпеки держави: сутність та особливості формування. Науковий вісник Міжнародного гуманітарного університету. Серія : Економіка і менеджмент, 26(1), с. 22-25.

Чубукова, О.Ю. та Воронкова, Т.Є., 2014. Система економічної безпеки (екосестейт): сутність, структура. Ефективна економіка, [онлайн] 2. Доступно: $<$ http://nbuv.gov.ua/UJRN/efek_2014_2_82> (Дата звернення: 15.09.2020).

Шевченко, М.M., 2015. Система критеріїв та показників оцінки поточної ефективності функціонування державного механізму реагування на загрози національним інтересам. Науково-інформачійний вісник Академї національної безпеки, 1-2. c.96-108.

Шлемко, В.Т та Бінько, І.Ф., 1997. Економічна безпека Украӥни: сутність і напрямки забезпечення. Київ: Національний інститут стратегічних досліджень.

\section{References}

Analitychna dopovid do shchorichnoho Poslannia Prezydenta Ukrainy do Verkhovnoi Rady Ukrainy «Pro vnutrishnie ta zovnishnie stanovyshche Ukrainy u 2018 rotsi» [Analytical Report to the Annual Address of the President of Ukraine to the Verkhovna Rada of Ukraine "On the Internal and External Situation of Ukraine in 2018], 2018. Kyiv: National Institute for Strategic Studies. (in Ukraine).

Chubukova, O.Iu. and Voronkova, T.Ie., 2014. Systema ekonomichnoi bezpeky (ekosesteit): sutnist, struktura [The system of economic security (ecosystem): essence, structure]. Efficient economy, [online] 2. Available at: http://nbuv.gov.ua/UJRN/efek_2014_2_82 (Accessed 15 September 2020). (in Ukraine).

Dmytruk, P.M., 2013. Instytutsionalizatsiia mekhanizmu derzhavnoho rehuliuvannia ekonomichnoi bezpeky Avtonomnoi Respubliky Krym [The institutionalization the mechanism of state regulation of economic security of the Autonomous Republic of Crimea]. Ph.D. thesis. National Academy of Public Administration under the President of Ukraine. (in Ukraine). 
Muntiyan, V.I., 1999. Ekonomichna bezpeka Ukrainy [Economic security of Ukraine]. Kyiv: KVITs (in Ukraine).

Reznikova, O.O., ed., 2015. Kontseptualni zasady rozvytku systemy zabezpechennia natsionalnoi bezpeky Ukrainy. Analitychna dopovid [Conceptual principles of development of the national security system of Ukraine. Analytical report ], 2015. Kyiv: National Institute for Strategic Studies. (in Ukraine).

Reznikova, O.O., red., 2020. Natsionalni systemy otsiniuvannia ryzykiv i zahroz: krashchi svitovi praktyky, novi mozhlyvosti dlia Ukrainy. Analitychna dopovid. [National systems of risk and threat assessment: best world practices, new opportunities for Ukraine. Analytical report], 2020. Kyiv: National Institute for Strategic Studies. (in Ukraine).

Rozporiadzhennia Kabinetu Ministriv Ukrainy Pro skhvalennia Enerhetychnoi stratehii Ukrainy na period do 2035 roku "Bezpeka, enerhoefektyvnist, konkurentospromozhnist" [Order of the Cabinet of Ministers of Ukraine On Energy Strategy of Ukraine for the period up to 2035 "Security, Energy Efficiency, Competitiveness"], 2017. Available at: $<$ https://zakon.rada.gov.ua/laws/show/6052017-\%D1\%80\#Text> (Accessed 09 September 2020). (in Ukraine).

Rozporiadzhennia Kabinetu Ministriv Ukrainy Pro skhvalennia Stratehii spryiannia zaluchenniu pryvatnykh investytsii u silske hospodarstvo na period do 2023 roku [Order of the Cabinet of Ministers of Ukraine On Approval of the Strategy to Promote Private Investment in Agriculture until 2023], 2019. Available at: $<$ https://zakon.rada.gov.ua/laws/show/595-2019-\%D1\%80\#Text> (Accessed 13 September 2020). (in Ukraine).

Sadovskiy, V.N., 1974. Osnovaniya obshchey teorii sistem: Logiko-metodologicheskiy analiz [Fundamentals of General Systems Theory: Logical and Methodological Analysis]. Moscow: Nauka. (in Russia).

Shevchenko, M.M., 2015. Systema kryteriiv ta pokaznykiv otsinky potochnoi efektyvnosti funktsionuvannia derzhavnoho mekhanizmu reahuvannia na zahrozy natsionalnym interesam [System of criteria and indicators for assessing the current effectiveness of the state mechanism for responding to threats to national interests]. Scientific journal of the Academy of national security, 1-2, pp.96-108.

Shlemko, V.T. and Binko, I.F., 1997. Ekonomichna bezpeka Ukrainy: sutnist i napriamky zabezpechennia. [Economic security of Ukraine : essence and directions of providing]. Kyiv: National Institute for Strategic Studies. (in Ukraine).

Ukaz Prezydenta Ukrainy Pro rishennia Rady natsionalnoi bezpeky i oborony Ukrainy vid 6 travnia 2015 roku "Pro Stratehiiu natsionalnoi bezpeky Ukrainy" [Decree of the President of Ukraine "On Decision of the National Security and Defence Council of Ukraine on May 5, 2015, "On the National Security Strategy of Ukraine”], 2015. Available at: https://zakon.rada.gov.ua/laws/show/287/2015\#Text (Accessed 09 September 2020). (in Ukraine).

Ukaz Prezydenta Ukrainy Pro rishennia Rady natsionalnoi bezpeky i oborony Ukrainy vid 14 veresnia 2020 roku "Pro Stratehiiu natsionalnoi bezpeky Ukrainy" [Decree of the President of Ukraine On the Decision of the National Security and Defense Council of Ukraine of September 14, 2020 "On the National Security Strategy of Ukraine"], 2020. Available at: https://zakon.rada.gov.ua/laws/show/392/2020\#Text (Accessed 20 September 2020). (in Ukraine).

Ukaz Prezydenta Ukrainy Pro Stratehiiu staloho rozvytku «Ukraina - 2020» [Decree of the President of Ukraine On the Sustainable Development Strategy "Ukraine-2020”], 2015. Available at: <https://zakon.rada.gov.ua/laws/show/5/2015\#Text> (Accessed 09 September 2020). (in Ukraine). 
Urba, S.I., 2017. Systema ekonomichnoi bezpeky derzhavy: sutnist ta osoblyvosti formuvannia [System of economic security of the state: essence and features of formation]. Scientific Bulletin of the International Humanities University. Series: Economika and management, 26(1), pp.22-25. (in Ukraine).

Zakon Ukrainy Pro natsionalnu bezpeku Ukrainy [Law of Ukraine on National Security of Ukraine], 2018. Available at: https://zakon.rada.gov.ua/laws/show/2469-19 (Accessed 13 September 2020). (in Ukraine).

Zakon Ukrainy Pro Radu natsionalnoi bezpeky i oborony Ukrainy [On Council of National Security and Defense of Ukraine], 1998. Available at: https://zakon.rada.gov.ua/laws/show/183/98-\%D0\%B2\%D1\%80\#\%3E (Accessed 20 September 2020). (in Ukraine).

Zhilin, D.M., 2004. Teoriya sistem: opyt postroeniya kursa [Systems Theory. Experience in Building a Course]. 2-nd ed. Moscow: URSS. (in Russia).

Стаття надійшла до редакції 20.10.2020

\section{Л. А. Кислова \\ В. Ю. Сук}

\section{ТРАНСФОРМАЦЙНІ ПЕРЕТВОРЕННЯ СИСТЕМИ ЗАБЕЗПЕЧЕННЯ ЕКОНОМІЧНОӦ БЕЗПЕКИ УКРАЇНИ}

У науковій статті зазначається, щуо здійснення заходів щуодо забезпечення економічної безпеки, як ключового елементу в структурі національної безпеки, $\epsilon$ фундаментальним чинником існування украӥнської державності, щцо в свою чергу вимагає створення та забезпечення функиіонування відповідної системи. 3 'ясовано, що сучасний стан системи забезпечення економічної безпеки держави не дозволяє ефективно протидіяти наявним та потенційним загрозам, а також створити умови для стабільного функиіонування вітчизняної економіки.

Встановлено, щзо ігнорування необхідності нормативного впорядкування, створення єдиної системи моніторингу, аналізу, прогнозування та прийняття рішень у сфрері економічної безпеки є основними факторами, щуо обумовлюють необхідність трансформаційних перетворень системи забезпечення економічної безпеки. Також, важливо змінити логіку ї̈ функиіонування від реагування на настання критичних умов в економіці, до здійснення превентивних заходів щэодо виявлення та попередження реальних і потенційних загроз на початковому етапі.

Обгрунтовано необхідність невідкладної гармонізачії органами законодавчої та виконавчої влади ряду нормативно-правових актів у сфері забезпечення національної та економічної безпеки з метою усунення їх взаємних критичних невідповідностей, наслідком яких є розпорочення обмежених матеріальних ресурсів, розкоординація діяльності суб'єктів забезпечення економічної безпеки, дублювання ӥх функиій. Необхідним кроком для иього є залучення представників міжнародних неурядових організацій та вітчизняних наукових установ, щуо спеціалізуються на вивченні проблем в економічній сфері.

Запропоновано проведення систематичного аудиту ефективності діяльності суб'єктів забезпечення економічної безпеки з метою визначення необхідності їх подальшої реорганізації. Важливим, в контексті проведення організаційних змін $\epsilon$ розширення функиіоналу Головного ситуаційного иентру України при РНБО, який повинен акумулювати та узагальнювати інформачію про сучасний стан економічної безпеки України, визначати тендениії змін ї̈ показників, вплив зовнішніх і внутрішніх 
чинників, а також постійно контролювати корупџію та організовану злочинність, здійснювати оцінку рівня тіньової економіки.

Ключові слова: економічна система, економічна безпека, загрози економічної безпеки, економічні показники.

УДК 338.486 .4

О.В. Макара

А.Ю. Котинський

\section{ПРИЙНЯТТЯ СТРАТЕГІЧНИХ РІШЕНЬ ПІДРИСМСТВАМИ СФЕРИ ТУРИЗМУ В УМОВАХ КОНКУРЕНЦЇ̈}

Викладено результати досліджень щодо розвитку та формування ефективної стратегії у туристичній сфері. На основі досліджень виявлено проблеми щзодо визначення стратегічних рімень підприємствами сфери туризму. Запропоновано структурно-логічну модель прийняття стратегічних рімень туристичного бізнесу в умовах конкуренції.

Ключові слова: стратегія, стратегічні рімення, сфера туризму, конкурентоспроможність, управління.

DOI 10.34079/2226-2822-2020-10-20-48-55

Постановка проблеми. Сфера туризму забезпечує вирішення економічних, соціальних, екологічних завдань. Ця галузь у світовій економіці випереджає нафтовидобуток й автомобілебудування за темпами зростання доходів та становить значну частину валового продукту.

Сфера туризму пов'язана 3 діяльністю більш як 50 галузей, іï розвиток сприяє підвищенню рівня зайнятості, диверсифікації національної економіки, збереженню і розвитку культурного потенціалу, збереженню екологічно безпечного навколишнього природного середовища, а також підвищує рівень інноваційності національної економіки, сприяє гармонізації відносин між різними країнами і народами [1].

В період глобалізаційних процесів, інформатизації, макроекономічної відкритості залучення громадян до пізнання навколишнього світу є новою компонентою сучасної парадигми туризму. Людська мобільність доступу до соціокультурного середовища різних країн і народів $є$ ключовим завданням євроінтеграційного курсу держави, що має забезпечити відкритість вітчизняної економіки. Це потребує чіткого визначення стратегічних рішень підприємствами сфери туризму, що буде першоосновою на шляху підвищення їх конкурентоспроможності на міжнародному ринку.

Аналіз останніх досліджень та публікацій. Теоретичні, методичні і практичні аспекти дослідження конкурентних переваг підприємств сфери туризму знайшли відображення в працях зарубіжних вчених, як Дж. Даннінг, М. Енрайт, Б. Йонсон, Б.-А. Лундвалль, Р. Уотермен, М. Портер, Б. Скотт, А. Томпсон та ін. Питання, пов'язані з визначенням та формуванням стратегії розвитку туристичної галузі знайшли відображення в працях вітчизняних та зарубіжних авторів, серед яких: Н. Алексєєва, М. Борущак, Д. Басюк, С. Білоус, Г. Горіна, В. Квартальнов, Н. Корж, М. Мальська, М. Моісєєва, Л. Погребняк, О. Савіцька, Н. Савіцька, Т. Ткаченко, О. Шершньова. Так, проблеми пошуку ефективних стратегій розглядаються в публікаціях таких сучасних вітчизняних науковців, як С. Дем'яненко, М. Круглової, В. Герасименко, Л. Балабанової. 